\title{
Bird survey in a forest mountain of Congo Basin (Eloumden, Cameroon) and diversity analysis confirm high diversity of world second reserve and correlation between species diversity and vegetation
}

\begin{abstract}
Our knowledge of the Congo Basin Forest, which is composed of six countries including Cameroon, and which is the world second Reserve in terms of Biodiversity after the Amazon, is almost non-existent because of few studies carried out in this great region. Some shy studies focused on biodiversity surveys have been undertaken within a few countries for some groups such as Arthropods, Plants, Mammals, etc. but very little about Birds. Here we present data on the bird survey conducted in a region of Cameroon. To perform the bird survey, we used mist-netting method during six months to obtain the abundance of bird species. In order to analyse diversity and distribution, we accomplished analyses with SAS/STAT and PAST softwares. We caught 158 individuals belonging to 20 birds' families, $70 \%$ of which came from passerine families and $30 \%$ from nonpasserine. Compared with previous surveys in the same region, we newly recorded one genus, Bradornis, and seven species, Trachyphonus purpuratus, Psalidoprocne fuliginosa, Ptyonoprogne fuligula, Bradornis fuliginosus, Cinnyris batesi, Chalcomitra adelberti and Acrocephalus baeticatus. This high avifaunistic diversity is supported by estimated values of diversity indexes which show an absence of supremacy of one species $\left(H^{\prime}=3.62\right)$ and an equal distribution of individuals in their environment $\left(J^{\prime}=0.92\right)$. With the value of the Simpson diversity index of 0.96 , our result confirms high diversity within the Eloumden avifauna. Our study confirms that the composition as well as the structure of the Eloumden mountain as observed in the field play a main role in the diversity of bird species at least at the local level. Based on our distribution and diversity analyses, the pattern of variation in distribution of birds in the Eloumden mountain appears to lean on environmental factors and particularly the vegetation, which played the main role with a bird mixture of poor and better dispersers, migratory and vagrant due to presence of luxuriant vegetation all year round, and this also explains the lesser competition noted $(\mathrm{D}=0.04)$.
\end{abstract}

Keywords: congo basin forest, bird survey, mist netting method, distribution and diversity analyses, avifauna
Volume 4 Issue 4 - 2019

\author{
Billy Nguembock, 1,2 Esther Diane Olivia \\ Azang,' Sali Mahamat' \\ 'Department of Animal Biology and Physiology, University of \\ Yaounde I, Cameroon \\ 2Department of biological sciences, University of Montreal, \\ Canada
}

Correspondence: Billy Nguembock, Laboratory of Zoology, Department of Animal Biology and Physiology, Ornithology Unit. University of Yaounde I, P. O. Box 8I2 Yaounde, Cameroon, Tel+00237694 |44294, Email billyngue@yahoo.fr

Received: September 30, 2019 | Published: November 29, 2019 
period. ${ }^{4}$ Based on these few bird surveys, passerine representatives are systematically more numerous than non-passerine. $\cdot^{3-5,18,19}$ As known now, relationships between the biodiversity and environment function through trophic interactions. Only it is more and more established that the relationship between biodiversity and an ecosystem within the environment is often related to the food-web structure found in these habitats. ${ }^{20}$ In the same way, Parsons et al., ${ }^{21}$ have also established a correlation between food areas and the presence or the absence of birds and according to Abrams ${ }^{22}$ in a given environment the rise in productivity plays a great role on the abundances of the trophic levels and it has an impact on the biodiversity which is often increased. But the bird surveys carried out in different regions of Cameroon did not bring information on relationships between birds and their life environment particularly on the principle of taxa distribution in their environment as well as conditions of their abundance. ${ }^{2-5,19}$ In this study carried out in one of the six countries covering the Congo Basin Forest, we mainly followed two purposes: firstly, we thoroughly investigated the avifauna of this mountain which shelters a big Forest from base to tip and secondly, we tried to explore the diversity, abundance and distribution within the Eloumden avifauna to propose hypotheses on their patterns of distribution as well as reasons of their diversity or abundance if it is established in their biotic environment.

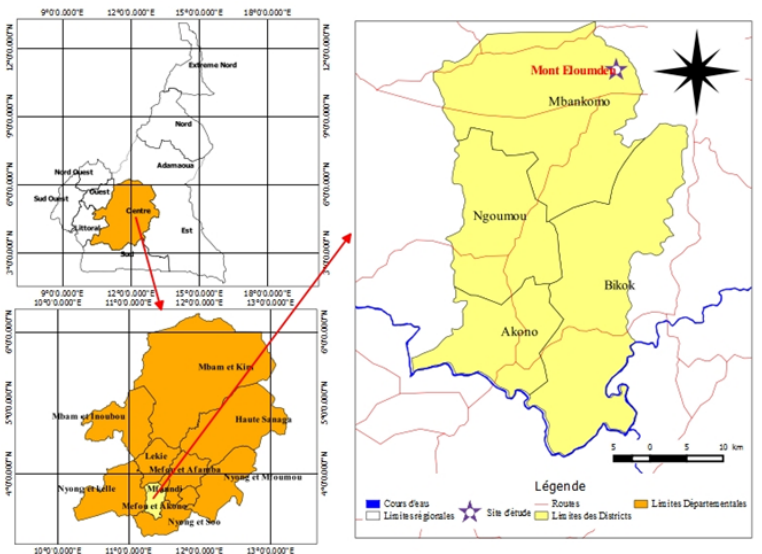

Figure I Localization of the Eloumden mountain (Congo Basin Forest, Cameroon).

\section{Material and methods}

\section{Investigation of the Eloumden avifauna}

To investigate the avifauna, we used an appropriate method: the mist-netting method. This method is widely used for catching small to medium-sized wild birds such as passerines and shorebirds. According to this method, an inconspicuous mesh net is erected vertically on poles and deployed in areas of high activity to intercept birds as they go about their normal daily routines. In our captures, we used darkcoloured nylon nets and smaller mesh for smaller species. Otherwise, our mist nets have a series of 3 pockets running horizontally along the length of the net. Our mist nets were fixed with the mounting poles which had been chosen carefully and the choice of an appropriate mist-netting site was important for the capture success. Thus in order to ensure the capture success, we mainly identified their preferred flight paths, feeding areas, roosting and shaded sites. Generally, we start catching very early in the morning (5:00AM) and we finish very late in the evening (sometimes 6:30PM). In order to avoid a skew in our survey, we used the same eight mist nets in our different field mission and we did eight field missions during six months.

\section{Method for the calculation of the relative abundance of the Eloumden avifauna}

In order to calculate the relative abundance, we chose to use the Statistical Analysis System. ${ }^{23}$ We input data as explained in the user guide and ran software until the obtaining of the results. Otherwise, we used Excel software program to obtain our histograms and curves. ${ }^{24}$

\section{Method for the calculation of the occurrence of the Eloumden avifauna}

In order to calculate the occurrence, we used the same software, the Statistical Analysis System. ${ }^{23}$ As for the calculation of the relative abundance, we input data as explained in the user guide and ran software until the obtaining of the results.

\section{Methods for the measure of the distribution of the Eloumden avifauna in line with their environment}

\section{Shannon index (H')}

The Shannon's diversity index represents the measure of the sum of degree of the uncertainty when it suggests predicting to which species would belong to an individual taken by chance in a collection of $\mathrm{S}$ species and $\mathrm{N}$ individuals. $H^{\prime}=0$ if the community has only one species; $H^{\prime}$ takes the maximal value $\log _{2} \mathrm{~S}$ only when all species are represented by the same number of individuals. This index is determined by the following relationship:

$$
\mathrm{H}^{\prime}=-\sum_{\mathrm{i}=1}^{\mathrm{S}}\left(\mathrm{p}_{\mathrm{i}} \mathrm{x} \log _{2} \mathrm{p}_{\mathrm{i}}\right) \mathrm{p}_{\mathrm{i}}=\mathrm{n}_{\mathrm{i}} / \mathrm{N}
$$

Where $p \mathrm{i}=$ proportion of individuals of the species "i"; $\mathrm{S}=$ total number of species of the sample.

$n \mathrm{i}=$ number of individuals of the species "i";

$\mathrm{N}=$ total number of individuals of the sample

The Shannon index $\left(H^{\prime}\right)$ increases when the number of the species of the community grows and, theoretically, it can reach elevated values. The value of $H^{\prime}$ varies from 1 to $\log _{2} \mathrm{~S}$. In our study, the Shannon index was calculated with the PAST software. ${ }^{25}$

\section{Simpson index $(\lambda)$}

The Simpson index represents the proportion of abundance of the species " $i$ ". ${ }^{25}$ This index measures the degree of concentration when individuals are classified into types. It is determined by the following relationship:

$$
\ddot{\mathrm{e}}=\sum_{\mathrm{i}=1}^{\mathrm{S}} \frac{\mathrm{n}_{\mathrm{i}}\left(\mathrm{n}_{\mathrm{i}}-1\right)}{\mathrm{n}(\mathrm{n}-1)}
$$

where $n \mathrm{i}=$ number of individuals of the species "i"; $n=$ total number of individuals of the sample.

Nevertheless, the most popular of such indexes have been the inverse Simpson index $(1 / \lambda)$ and the Gini-Simpson index $(1-\lambda)$ and both have also been called the Simpson index in the ecological literature. In our study, the Simpson index was calculated with the PAST software. ${ }^{25}$ 


\section{Equitability index}

The Equitability index measures the distribution of individuals within species independently to the specific richness. Its value varies from 0 (supremacy of one species) to 1 (equal distribution of individuals within species).

Thus, the Equitability index of Pielou $\left(J^{\prime}\right)$ is determined by the following formula:

$$
\begin{aligned}
& J^{\prime}=H^{\prime} / H^{\prime} \max \\
& H^{\prime}=\text { Shannon index }
\end{aligned}
$$$$
H^{\prime} \max =\log _{2} \mathrm{~S}(\mathrm{~S}=\text { the total number of species }) \text {. }
$$

In our study, the Equitability index was calculated with the PAST software. ${ }^{25}$

All these indexes have been obtained with a confidence threshold of $95 \%$.

\section{Results}

\section{Abundance and occurrence of the Eloumden avifauna}

Familial abundances of the Eloumden avifauna:We caught 158 individuals belonging to 20 birds families (Table 1). The most representative family is the Pycnonotidae family with 31 of the 158 captured individuals (19.62\%) (Figure $2 \&$ Table 1$)$. We found that $70 \%$ of the captures were from the passerine families and $30 \%$ from non-passerine (Table 1). The Pycnonotidae family was the more diversified with five genera and seven species, followed by the Nectariniidae family with four genera and eight species and the Estrildidae family with four genera and four species (Tables 2\&3).

Table I Familial abundance of the Eloumden avifauna obtained after the bird survey between September 2015 and February 2016 in the relictual Eloumden mountain of the Congo Basin Forest

\begin{tabular}{lll}
\hline Families & $\begin{array}{l}\text { Absolute } \\
\text { abundance }\end{array}$ & $\begin{array}{l}\text { Relative } \\
\text { abundance(\%) }\end{array}$ \\
\hline Alcedinidae & 3 & 1.9 \\
Coliidae & 3 & 1.9 \\
Columbidae & 9 & 5.7 \\
Cuculidae & 2 & 1.27 \\
Estrildidae & 9 & 5.7 \\
Fringillidae & 1 & 0.63 \\
Hirundinidae & 14 & 8.86 \\
Lybiidae & 20 & 12.66 \\
Malaconotidae & 7 & 4.43 \\
Monarchidae & 4 & 2.53 \\
Muscicapidae & 3 & 1.9 \\
Nectariniidae & 20 & 12.66 \\
Nicatoridae & 5 & 3.16 \\
Picidae & 1 & 0.63 \\
Platysteiridae & 1 & 0.63 \\
Ploceidae & 15 & 9.49 \\
Pycnonotidae & 31 & 19.62 \\
Sylviidae & 5 & 3.16 \\
Turdidae & 5 & 3.16 \\
TOTAL & 158 & 100 \\
\hline
\end{tabular}

Table 2 Generic abundance of the Eloumden avifauna obtained after the bird survey between September 2015 and February 2016 in the relictual Eloumden

\begin{tabular}{|c|c|c|}
\hline Genera & $\begin{array}{l}\text { Absolute } \\
\text { abundance }\end{array}$ & $\begin{array}{l}\text { Relative } \\
\text { abundance (\%) }\end{array}$ \\
\hline Acrocephalus & 1 & 0.63 \\
\hline Amblyospiza & 2 & 1.27 \\
\hline Camaroptera & 2 & 1.27 \\
\hline Campethera & 1 & 0.63 \\
\hline Ceyx & 2 & 1.27 \\
\hline Chalcomitra & 1 & 0.63 \\
\hline Chlorocichla & 10 & 6.33 \\
\hline Chrysococcyx & 2 & 1.27 \\
\hline Cinnyris & 10 & 6.33 \\
\hline Colius & 3 & 1.9 \\
\hline Cyanomitra & 9 & 5.7 \\
\hline Dryoscopus & 3 & 1.9 \\
\hline Estrilda & 1 & 0.63 \\
\hline Eurillas & 13 & 8.23 \\
\hline Gymnobucco & 13 & 8.23 \\
\hline Halcyon & 1 & 0.63 \\
\hline Hedydipna & 1 & 0.63 \\
\hline Ptynoprogne & 2 & 1.27 \\
\hline Hylia & 2 & 1.27 \\
\hline Laniarus & 1 & 0.63 \\
\hline Lonchura & 1 & 0.63 \\
\hline Mandingoa & 1 & 0.63 \\
\hline Bradornis & 3 & 1.9 \\
\hline Nicator & 1 & 0.63 \\
\hline Ochrospiza & 1 & 0.63 \\
\hline Platysteira & 1 & 0.63 \\
\hline Ploceus & 13 & 8.23 \\
\hline Pogoniulus & 4 & 2.53 \\
\hline Psalidoprocne & 11 & 6.96 \\
\hline Pycnonotus & 11 & 6.96 \\
\hline Spermophaga & 6 & 3.8 \\
\hline Tchagra & 3 & 1.9 \\
\hline Terpsiphone & 4 & 2.53 \\
\hline Thescelocichla & 1 & 0.63 \\
\hline Trachylaemus & 3 & 1.9 \\
\hline Turdus & 5 & 3.16 \\
\hline Turtur & 9 & 5.7 \\
\hline TOTAL & 158 & 100 \\
\hline
\end{tabular}
mountain of the Congo Basin Forest 
Table 3 Specific abundance and occurrence of each captured species of the Eloumden avifauna during the bird survey between September 2015 and February 2016 in the relictual Eloumden mountain of the Congo Basin Forest (Central Africa)

\begin{tabular}{|c|c|c|c|c|c|}
\hline Scientific name & Frequency & Common name & $\begin{array}{l}\text { Occurrence } \\
\text { (\%) }\end{array}$ & $\begin{array}{l}\text { Absolute } \\
\text { abundance }\end{array}$ & $\begin{array}{l}\text { Relative } \\
\text { abundance (\%) }\end{array}$ \\
\hline $\begin{array}{l}\text { Acrocephalus } \\
\text { baeticatus }\end{array}$ & 1 & African Reed-warbler & 12.5 & 1 & 0.63 \\
\hline Amblyospiza albifrons & 2 & Thick-billed Weaver & 25 & 2 & 1.27 \\
\hline Bradornis fuliginosus & 1 & Sooty Flycatcher & 12.5 & 3 & 1.9 \\
\hline $\begin{array}{l}\text { Camaroptera } \\
\text { brachyura }\end{array}$ & 2 & $\begin{array}{l}\text { Green-backed } \\
\text { Camaroptera }\end{array}$ & 25 & 2 & 1.27 \\
\hline Campethera cailliautii & 1 & $\begin{array}{l}\text { Little Spooted } \\
\text { Woodpecker }\end{array}$ & 12.5 & I & 0.63 \\
\hline Chalcomitra adelberti & 1 & Buff-throated Sunbird & 12.5 & 1 & 0.63 \\
\hline $\begin{array}{l}\text { Chlorocichla } \\
\text { falkeinsteini }\end{array}$ & 3 & Yellow-necked Greenbul & 37.5 & 3 & 1.9 \\
\hline Chlorocichla simplex & 5 & Simple Greenbul & 62.5 & 7 & 4.43 \\
\hline Chrysococcyx cupreus & 1 & African Emerald Cuckoo & 12.5 & 1 & 0.63 \\
\hline Chrysococcyx klaas & 1 & Klaas's Cuckoo & 12.5 & 1 & 0.63 \\
\hline Cinnyris batesi & 1 & Bates's Sunbird & 12.5 & I & 0.63 \\
\hline Cinnyris chloropygius & 1 & Olive-bellied Sunbird & 12.5 & 2 & 1.27 \\
\hline Cinnyris minullus & 1 & Tiny Sunbird & 12.5 & 1 & 0.63 \\
\hline Cinnyris superbus & 4 & Superb Sunbird & 50 & 6 & 3.8 \\
\hline Colius striatus & 2 & Speckled Mousebird & 25 & 3 & 1.9 \\
\hline Cyanomitra obscura & 3 & Western Olive Sunbird & 37.5 & 4 & 2.53 \\
\hline Cyanomitra verticalis & 3 & Green-headed Sunbird & 37.5 & 5 & 3.16 \\
\hline $\begin{array}{l}\text { Dryoscopus } \\
\text { senegalensis }\end{array}$ & 3 & Red-eyed Puffback & 37.5 & 3 & 1.9 \\
\hline Estrilda melpoda & I & Orange-cheeked Waxbill & 12.5 & I & 0.63 \\
\hline Eurillas latirostris & 5 & $\begin{array}{l}\text { Yellow-whiskered } \\
\text { Greenbul }\end{array}$ & 62.5 & 8 & 5.06 \\
\hline Eurillas virens & 2 & Little Greenbul & 25 & 5 & 3.16 \\
\hline $\begin{array}{l}\text { Gymnobucco } \\
\text { bonapartei }\end{array}$ & 5 & Grey-throated Barbet & 62.5 & 13 & 8.23 \\
\hline Halcyon senegalensis & 1 & Woodland Kingfisher & 12.5 & I & 0.63 \\
\hline Hedydipna collaris & I & Collared Sunbird & 12.5 & I & 0.63 \\
\hline
\end{tabular}

Citation: Nguembock B,Azang EDO, Mahamat S. Bird survey in a forest mountain of Congo Basin (Eloumden, Cameroon) and diversity analysis confirm high diversity of world second reserve and correlation between species diversity and vegetation. Int J Avian \& Wildlife Biol. 20I 9;4(4):I I8-I27. DOI: 10.15406/ijawb.2019.04.00163 


\begin{tabular}{|c|c|c|c|c|c|}
\hline Scientific name & Frequency & Common name & $\begin{array}{l}\text { Occurrence } \\
\text { (\%) }\end{array}$ & $\begin{array}{l}\text { Absolute } \\
\text { abundance }\end{array}$ & $\begin{array}{l}\text { Relative } \\
\text { abundance (\%) }\end{array}$ \\
\hline Hylia prasina & 1 & Green Hylia & 12.5 & 2 & 1.27 \\
\hline Ispidina picta & 2 & African Pygmy-kingfisher & 25 & 2 & 1.27 \\
\hline Laniarius luehderi & 1 & Luehder's Bushrike & 12.5 & 1 & 0.63 \\
\hline Lonchura bicolor & I & Black-and-white Mannikin & 12.5 & I & 0.63 \\
\hline Mandingoa nitidula & I & Green-backed Twinspot & 12.5 & 1 & 0.63 \\
\hline Nicator vireo & 1 & Yellow-throated Nicator & 12.5 & 1 & 0.63 \\
\hline $\begin{array}{l}\text { Ochrospiza } \\
\text { mozambica }\end{array}$ & 1 & Yellow-fronted Canary & 12.5 & 1 & 0.63 \\
\hline Platysteira cyanea & I & $\begin{array}{l}\text { Brown-throated Wattle- } \\
\text { eye }\end{array}$ & 12.5 & 1 & 0.63 \\
\hline Ploceus cucullatus & 5 & Village Weaver & 62.5 & 8 & 5.06 \\
\hline Ploceus nigerrimus & 2 & Viellot's Black Weaver & 25 & 2 & 1.27 \\
\hline Ploceus nigricollis & 2 & Black-necked Weaver & 25 & 3 & 1.9 \\
\hline Pogoniulus atroflavus & 1 & Red-rumped Tinkerbird & 12.5 & 1 & 0.63 \\
\hline Pogoniulus bilineatus & 2 & $\begin{array}{l}\text { Yellow-rumped } \\
\text { Tinkerbird }\end{array}$ & 25 & 3 & 1.9 \\
\hline $\begin{array}{l}\text { Psalidoprocne } \\
\text { fuliginosa }\end{array}$ & 2 & Mountain Sawwing & 25 & 7 & 4.43 \\
\hline $\begin{array}{l}\text { Psalidoprocne } \\
\text { pristoptera }\end{array}$ & 3 & Black Saw-wing & 37.5 & 4 & 2.53 \\
\hline Ptyonoprogne fuligula & 1 & Large Martin Rock & 12.5 & 2 & 1.27 \\
\hline Pycnonotus barbatus & 4 & Common Bulbul & 50 & 11 & 6.96 \\
\hline $\begin{array}{l}\text { Spermophaga } \\
\text { haematina }\end{array}$ & 4 & Western Bluebill & 50 & 6 & 3.8 \\
\hline Tchagra australis & 2 & Brown-crowned Tchagra & 25 & 3 & 1.9 \\
\hline Terpsiphone batesi & 2 & $\begin{array}{l}\text { Bates's Paradise- } \\
\text { flycatcher }\end{array}$ & 25 & 2 & 1.27 \\
\hline $\begin{array}{l}\text { Terpsiphone } \\
\text { rufocinerea }\end{array}$ & 1 & $\begin{array}{l}\text { Rufous-vented Paradise- } \\
\text { Flycatcher }\end{array}$ & 12.5 & 1 & 0.63 \\
\hline Terpsiphone viridis & I & $\begin{array}{l}\text { African Paradise- } \\
\text { Flycatcher }\end{array}$ & 12.5 & 1 & 0.63 \\
\hline $\begin{array}{l}\text { Thescelocichla } \\
\text { leucopleura }\end{array}$ & 1 & Swamp Palm Bulbul & 12.5 & 1 & 0.63 \\
\hline $\begin{array}{l}\text { Trachylaemus } \\
\text { purpuratus }\end{array}$ & 3 & $\begin{array}{l}\text { Eastern Yellow-billed } \\
\text { Barbet }\end{array}$ & 37.5 & 3 & 1.9 \\
\hline Turdus pelios & 3 & African Thrush & 37.5 & 5 & 3.16 \\
\hline Turtur afer & 3 & Blue-spotted Wood Dove & 37.5 & 6 & 3.8 \\
\hline Turtur tympanistria & 3 & Tambourine Dove & 37.5 & 3 & 1.9 \\
\hline Total & & & & 158 & 100 \\
\hline
\end{tabular}

Citation: Nguembock B,Azang EDO, Mahamat S. Bird survey in a forest mountain of Congo Basin (Eloumden, Cameroon) and diversity analysis confirm high diversity of world second reserve and correlation between species diversity and vegetation. Int J Avian \& Wildlife Biol. 20I9;4(4):I I8-I27. DOI: 10.15406/ijawb.2019.04.00163 


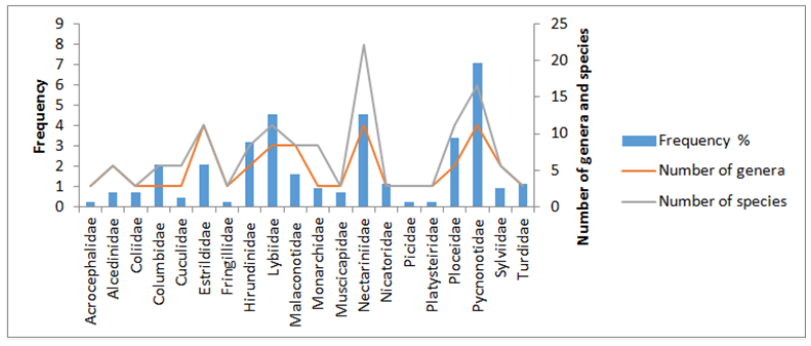

Figure 2 Relative familial abundance histogram in function of genera and species captured during the bird survey between September 2015 and February 2016 in the relictual Eloumden mountain of the Congo Basin Forest.

\section{Generic abundances and occurrences of the Eloumden avifauna}

The 158 captured individuals belong to 37 genera (Table 2). The most representative genera are those of two passerine, Eurillas (Pycnonotidae) and Ploceus (Ploceidae), and one non-passerine, Gymnobucco (Lybiidae) (Figure $3 \&$ Table 2). The less representative genera with a relative abundance of $0.63 \%$ are those belonging to eleven passerine, Acrocephalus, Chalcomitra, Estrilda, Hedydipna, Laniarius, Lonchura, Mandingoa, Nicator, Ochrospiza, Platysteira and Thescelocichla, and the two remaining belong to non-passerine, Campethera and Halcyon (Table 2).

According to Dajoz ${ }^{26} 43.24 \%$ of the genera sampled were rare. However within the most representative Pycnonotidae family, genera Eurillas and Chlorocichla appeared very frequent, both of them having an occurrence of $75 \%$. According to our results, four other have been frequent; it was about Ploceus, Cinnyris, Cyanomitra and Gymnobucco.

\section{Specific abundances and occurrences of the Eloumden avifauna}

According to our occurrence results, only $13.72 \%$ of captured birds are relatively common including five passerine members, Chlorocichla simplex, Eurillas latirostris, Pycnonotus barbatus, Cinnyris superbus and Spermophaga haematina, and one non-passerine member, Gymnobucco bonapartei (Table 3). According to Dajoz ${ }^{26}$ species less commonly encountered included fourteen passerine members, Ambyospiza albifrons, Camaroptera brachyura, Chlorocichla falkensteini, Cyanomitra obscura, Cyanomitra verticalis, Dryoscopus senegalensis, Ploceus nigerrimus, Ploceus nigricollis, Psalidoprocne pristoptera, Psalidoprocne fuliginosa, Tchagra australis, Terpsiphone batesi and Turdus pelios, and six non-passerine members, Ceyx pictus, Colius striatus, Pogoniulus bilineatus, Trachylaemus pupuratus, Turtur afer and Turtur tympanistria (Table 3). Always according to $\mathrm{Dajoz}^{26}$ our analyses show clearly that the major part of species (47.06\%) sampled were simply rare (Table 3 ).

\section{Diversity indexes}

The Shannon index was of 2.56 (familial level), 3.21 (generic level) and 3.62 (specific level) (Table 4). Concerning the Simpson index, values were of 0.90 (familial level), 0.95 (generic level) and 0.96 (specific level) (Table 4). As for the Shannon index, the general tendency is the same than the Simpson index with high values (Table 4). The Equitability index values were of 0.85 (familial level), 0.89 (generic level) and 0.92 (specific level) (Table 4); we noted that these last values appear far from 0 (Table 4).
Table 4 Diversity indexes of the Eloumden avifauna within their life environment obtained from the PAST software. ${ }^{25}$

\begin{tabular}{llll}
\hline Taxinomic level & Family & Generic & specific \\
\hline Taxa S & 20 & 37 & $5 \mathrm{I}$ \\
Individuals & $\mathrm{I} 58$ & $\mathrm{I} 58$ & $\mathrm{I} 58$ \\
Dominance_D & 0.1 & 0.05 & 0.04 \\
Simpson_I-D & 0.9 & 0.95 & 0.96 \\
Shannon_H & 2.56 & 3.21 & 3.62 \\
Equitability_J & 0.85 & 0.89 & 0.92 \\
\hline
\end{tabular}

\section{Discussion}

\section{Avifauna of the Eloumden mountain, a mount of the congo basin forest}

The biodiversity of the Congo Basin Forest is of world global importance because of the species richness but also because this Forest harbors the most diverse assemblage of plants and animals in Africa including more than 1000 bird species. ${ }^{1}$ In Cameroon, more than 970 bird species (resident, passage migrant, intra-African migrant, Palearctic migrant, visitor and vagrant) are recorded and especially according to surveys carried out, representatives of the passerines are always more numerous. ${ }^{2-4,6,7,10}$ As for previous surveys, the Eloumden mountain survey confirms the high representativeness of the passerines compared with the non-passerines (Table 1). More generally in line with the Centre region of Cameroon, some non-passerine families such as Lybiidae, Columbidae, Cuculidae, Coliidae, Picidae and Alcedinidae have been already mentioned and several passerine families among them Pycnonotidae, Sylviidae, Ploceidae, Estrildidae, Fringillidae, Hirundinidae, Nectariniidae, Monarchidae, Malaconotidae, Muscicapidae, Platysteiridae, Turdidae have been pointed out but until now most of these non-passerine and passerine families are not directly mentioned in relation with the relictual Eloumden mountain., ${ }^{3,4}$ Newly we found species' representatives of the non-passerine families (Lybiidae) and passerine families (Hirundinidae, Muscicapidae, Nectariniidae, Nicatoridae) in the Centre region of Cameroon (Tables 1\&3). According to our results, one new genus, Bradornis, and seven new species, until now not recorded in this mountain of the Congo Basin Forest, it's about:

Trachyphonus purpuratus Verreaux \& Verreaux, 1851 belongs to the Lybiidae's family ${ }^{27}$ (Figure 4): this species has an extremely large range but until now, it is not recorded in this region. This pretty barbet has a large repertoire and has been caught in November 2015 during the breeding season; it is a common forest resident and sedentary bird. $^{28,29}$

Psalidoprocne fuliginosa Shelley, 1887 belongs to the Hirundinidae's family ${ }^{27}$ (Figure 5): until now recorded only in Cameroon mountain and Bioko, this swallow is known for its seasonal movements. ${ }^{28}$ According to del Hoyo et al. ${ }^{29}$ it is probably a resident but some records suggested possible post-breeding movements. We have just caught some specimens in another mountain of this region (Febe mountain).

Ptyonoprogne fuligula Lichtenstein, 1842 belongs to the Hirundinidae's family ${ }^{27}$ (Figure 6): this small bird has an extremely large range from Northern to Southern Africa but until now, it is not formally recorded in this region. Sometimes described as a common resident, this swallow has been recorded as a vagrant bird in Gabon. ${ }^{30}$ 
We caught it in December 2015 during its breeding season.

Bradornis fuliginosus Cassin, 1855 belongs to the Muscicapidae' family ${ }^{27}$ (Figure 7): this species has an extremely large range but it has not been recorded by Germain et al., ${ }^{3}$ and Louette ${ }^{4}$ it is an uncommon or local common forest resident throughout range but often possibly and locally abundant. ${ }^{29}$

Cinnyris batesi Ogilvie-Grant, 1908 belongs to the Nectariniidae's family ${ }^{27}$ (Figure 8): restricted in some countries of the Gulf of Guinea but also found from eastern Liberia, Ivory Coast and Ghana, this species is a rare or local common forest resident. ${ }^{28}$ In Cameroon, this sunbird is especially abundant in the South and until now, it was not recorded in this area. ${ }^{3,4}$

Chalcomitra adelberti Gervais, 1833 belongs to the Nectariniidae's family ${ }^{27}$ (Figure 9): until now recorded from Sierra Leone to South East of Nigeria but also in west of Cameroon, this species is never recorded in this region; ${ }^{3,4,28}$ it is a general uncommon or local common forest resident throughout range..$^{29}$

Acrocephalus baeticatus Vieillot, 1817 belongs to the Acrocephalidae's family ${ }^{27}$ (Figure 10): this species has a large range but it is patchily distributed. In Cameroon, this African reed warbler was restricted in North-West and South of Cameroon and until now, it was not recorded in this relictual area. ${ }^{28}$ Only, it is an intra-African migrant. ${ }^{28}$ Concerning its song, we noted that it is a rhythmic series of repeated squeaky notes (Billy Nguembock personal observation).

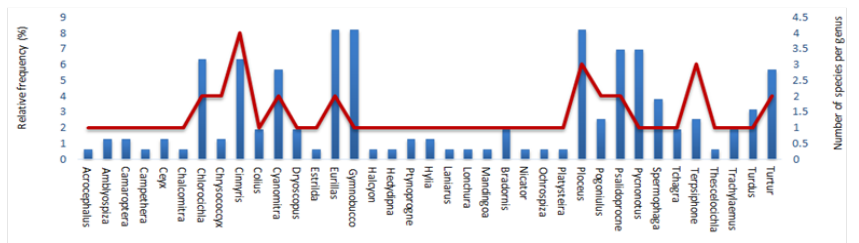

Figure 3 Relative frequency histogram of genera in function of number of captured species during the bird survey between September 2015 and February 2016 in the relictual Eloumden mountain of the Congo Basin Forest.

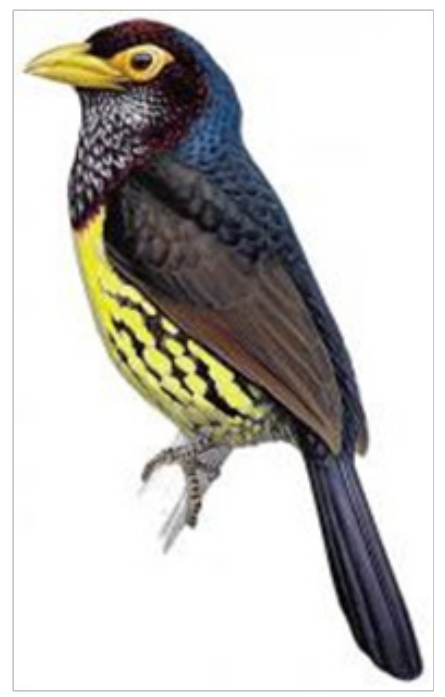

Figure 4 Trachyphonus purpuratus Verreaux \& Verreaux, I85I.

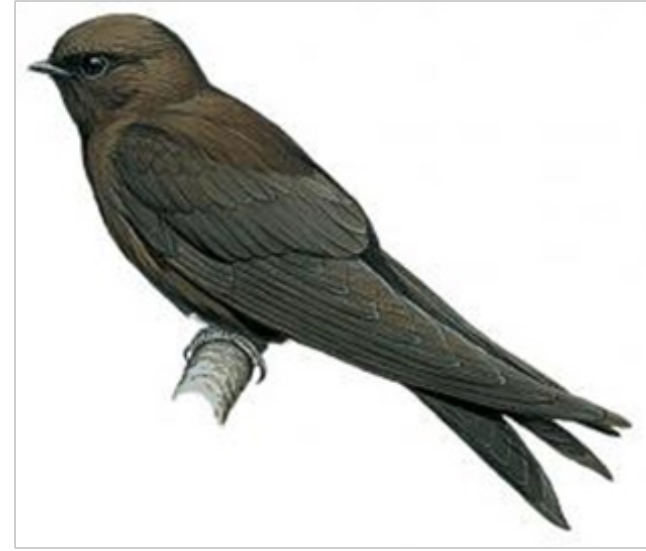

Figure 5 Psalidoprocne fuliginosa Shelley, 1887.

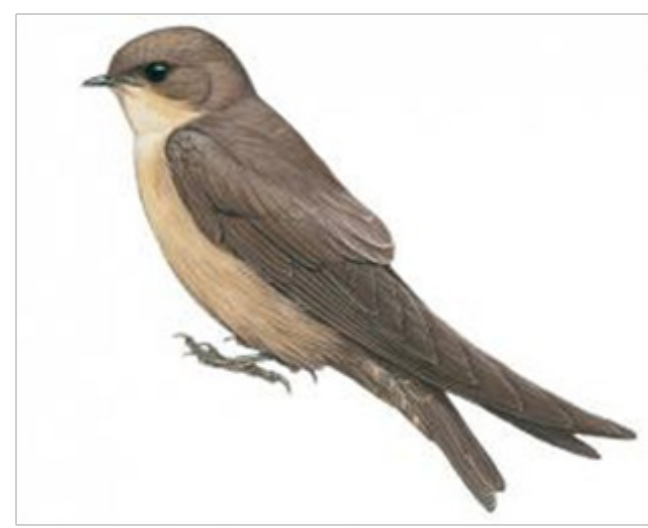

Figure 6 Ptyonoprogne fuligula Lichtenstein, 1842

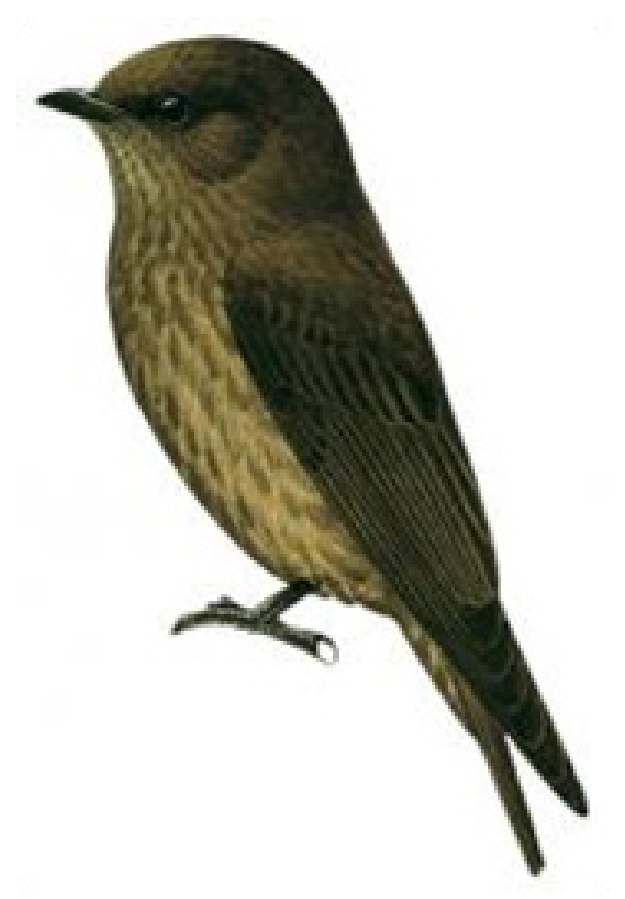

Figure 7 Bradornis fuliginosus Cassin, 1855.

Citation: Nguembock B, Azang EDO, Mahamat S. Bird survey in a forest mountain of Congo Basin (Eloumden, Cameroon) and diversity analysis confirm high diversity of world second reserve and correlation between species diversity and vegetation. Int J Avian \& Wildlife Biol. 20I9;4(4):I I8-I27. DOI: 10.15406/ijawb.2019.04.00163 


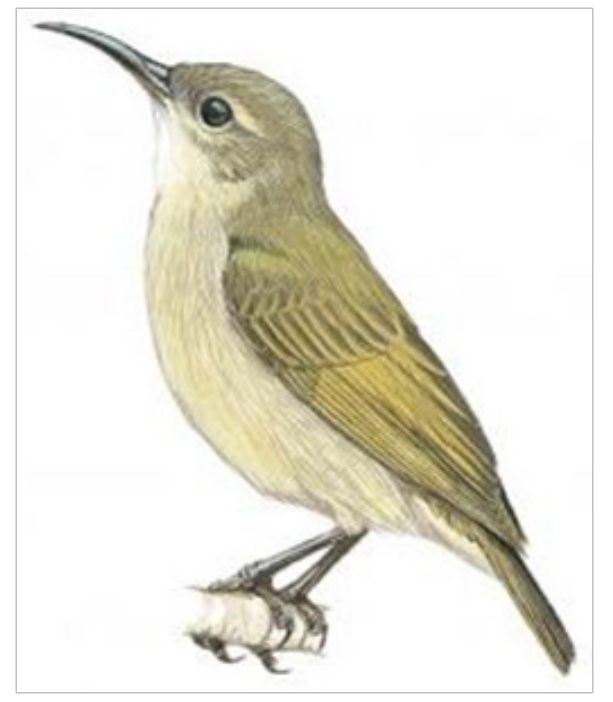

Figure 8 Cinnyris batesi Ogilvie-Grant, 1908.

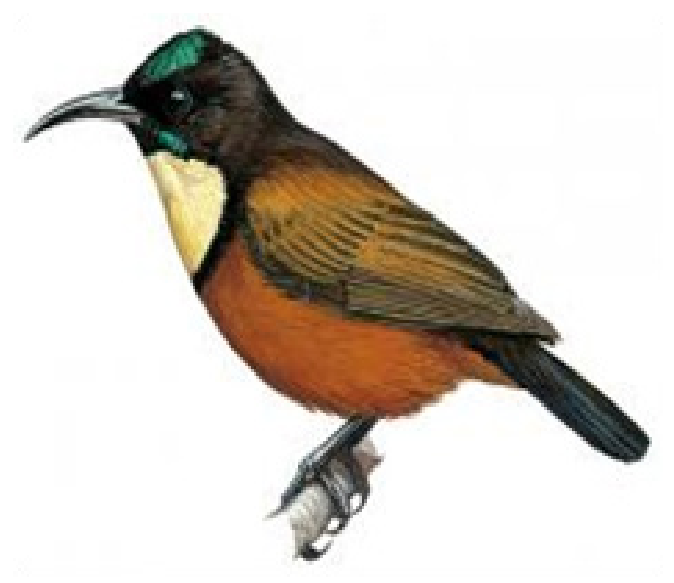

Figure 9 Chalcomitra adelberti Gervais, 1833.

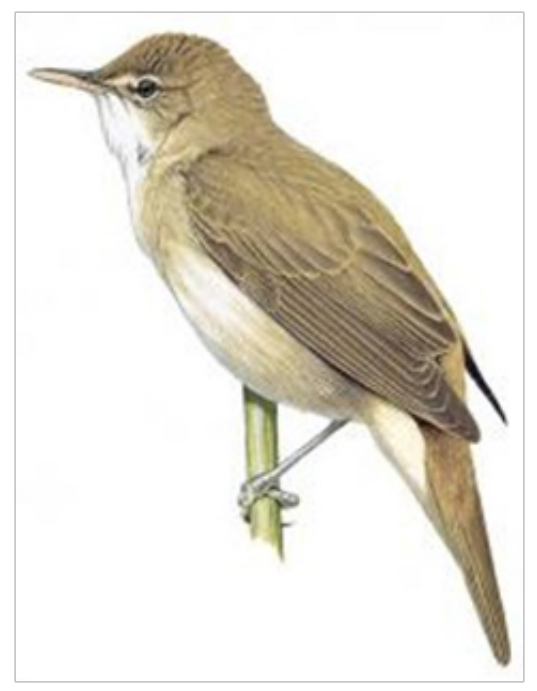

Figure 10 Acrocephalus baeticatus Vieillot, 1817.

\section{Distribution and diversity of the avifauna in the Eloumden mountain}

Based on statistical analyses, this mountain of Congo Rainforest shows high avifaunistic diversity from base to tip (Table 4). Our results show an absence of supremacy of one species $\left(H^{\prime}=3.62\right.$; Table 4); therefore, species have practically the same abundance. Generally, ecological biogeographers explain patterns of variation in the distribution of the species using environmental factors ${ }^{31,32}$ but other authors such as Hawkins et al., ${ }^{33}$ and Fjeldsa et al., ${ }^{34}$ tried to link the interaction between evolutionary and environmental factors. Concerning the relictual Eloumden mountain, firstly in this mountain, the vegetation appears uniform from the base to tip with by place the primary forest and sometimes the secondary forest intermixed with scrub land. ${ }^{35}$ Secondly in the Eloumden avifauna, we found a mixture of poor dispersers (specialists) such as Nectariniidae, etc. and better dispersers (generalists) such as Fringillidae, etc or even migratory birds such as Acrcephalus baeticatus, etc.; this mixture of taxa should be thus essentially due to the presence of luxuriant vegetation all year round. In fact, the particularity of the Eloumden mountain with the hillside in front of the wind is that it offers favourable conditions for birds in this ecosystem. ${ }^{12}$ Louette $^{4}$ revealed that the distribution of some Cameroonian birds seems to be directly related to the vegetation; the distribution within this mountain corroborates this principle with the obtained Equitability index $\left(J^{\prime}=0.92\right.$ species, Table 4) which suggests an equal distribution of individuals in this environment. As for the two first index values, the Simpson diversity index obtained of 0.96 goes in the same way (Table 4); this value supports a high avifaunistic diversity and especially confirms the tendency of an absence of supremacy of one species which could be explained by lush vegetation from the base to the summit. Thus as Louette ${ }^{4}$ our study suggests that the pattern of variation in distribution of birds in the Eloumden mountain appears to lean on environmental factors and particularly the vegetation.

\section{Correlation between species variety and availability of food in the Eloumden mountain}

Based on captured individuals, the Pycnonotidae family appeared the most abundant, followed by the Nectarinidae family as well as the Lybiidae family (Figure $2 \&$ Table 1). Always according to our results, the Nectariniidae family appeared the most diversified, followed by the Pycnonotidae family (Figure 3). Thus concerning passerine birds within the abundant Pycnonotidae family, there is genera Chlorocichla (C. simplex with $\mathrm{FO}=62.5 \%)$ and Eurillas $(E$. latirostris with $\mathrm{FO}=62.5 \%$ ) while within the abundant Nectariniidae family, there is two genera (Cinnyris and Cyanomitra) with a lot of species which had a weak frequency of occurrence (Table 3). For non-passerine birds, only one genus Gymnobucco ( $G$. bonapartei with $\mathrm{FO}=62.5 \%$ ) appeared abundant (Table 3). Globally, abundantly captured birds are forest species, although they can be found in other biotopes, which clearly shows that the study site is actually primary forest, although it appears to be degraded to some places. ${ }^{12}$ Thus for members of Pycnonotidae caught, Eurillas latirostris and Chlorocihla simplex eat almost essentially fruits and berries and sometimes they glean insects from the vegetation. ${ }^{28,29}$ Representatives of Cyanomitra and Cinnyris, Cyanomitra verticalis mainly eats small fruits and seeds, oil-palm sap as well as nectar from wide variety of flowers while Cinnyris superbus eats nectar from several flowers, seeds including those of Xylopia aethiopica, fruits but also insects, spiders and snails. ${ }^{28,29}$ Cyanomitra obscura eats insects, spiders, nectar, pollen, 
small berries, seeds, fruits and banana pulp. ${ }^{29}$ Concerning the African barbet Gymnobucco bonapartei, it eats essentially diverse fruits and berries such as figs and those of Allophyllus, Ficus, Musanga, etc. ${ }^{28,29}$ In their study, Rajpar and Zakaria ${ }^{36}$ revealed that the habitat characteristics such as vegetation composition, vegetation structures and microclimate variables are the key factors that influenced the distribution, diversity and density of the wetland bird species. But more specifically in their recent study, Girma et al., ${ }^{37}$ noted a high correlation between the availability of food and cover in a given environment and the abundance of bird species; according to these authors ${ }^{37}$ and Kiros et al., ${ }^{38}$ the abundance of bird species is directly affected by the availability of food sources in an ecosystem which is mainly influenced by vegetation composition and structure. We note that the structure as well as the composition of the Eloumden vegetation are particularly influenced by the hillside in front of the wind which receives lots of sun and precipitations throughout the year and constitutes an abundant food source for many birds, ${ }^{12}$ always according to the same author, ${ }^{12}$ in some places, human activities, especially some work field, have significantly altered the vegetation with fruit trees and vegetables. Thus the vegetation of the Eloumden mountain offers a food source for many birds among them seeds, fruits, berries, nectar from diverse flowers as well as fruit trees and vegetables, and this would certainly explain the species variety caught in this mountain Eloumden of the Congo Basin Forest.

\section{Conclusion}

The Eloumden forest mountain in the Congo Basin Forest has highlighted the great diversity of birdlife in the world's second largest reserve. On the other hand, this current study strongly confirms that the structure as well as the composition of vegetation play a main role in the species diversity at least at the local level. Indeed, the vegetation of the Eloumden mountain which receive lots of sun and precipitations throughout the year offers, through the permanent growth of plants, a food sources for many birds among them seeds, fruits, berries, nectar from diverse flowers as well as fruit trees and vegetables. Otherwise based on our diversity and distribution analyses, the pattern of variation in distribution of birds in the Eloumden mountain appears to lean on environmental factors and, once again in this case the vegetation which played the main role with a bird mixture of poor and better dispersers, migratory and vagrant due to presence of luxuriant vegetation all year round and this would explain the lesser competition noted $(\mathrm{D}=0.04)$.

\section{Acknowledgments}

This work was conducted with the permission of the chief of the Eloumden I village, his majesty BOMBA, who permitted us to carry out this study. We wish to thank the guide, Mr. Aimé, for all his efforts and his good knowledge of the study site which facilitated birds capture. We also wish to thank Miss BIDJA Bernadette for her help during this study. We thank the Zoology Laboratory of the University of Yaounde I especially the ornithological team for the technical material which has been used for the realization of this scientific work. We also thank all persons especially Mr. MBOG Jacques who have read this paper to ameliorate its quality through his scientific comments.

\section{Conflicts of interest}

Authors declare that there is no conflict of interest.

\section{References}

1. WWF. Certification and Roudtables: Do they work? WWF review of multi-stakeholder sustainability initiatives. WWF review. 2010.

2. Good AI. The birds of French Cameroon. Mémoires de l'IFAN, Centre du Cameroun, Sciences Naturelles. 1952;2:1-203.

3. Germain M, Dragesco J, Roux F, et al. Contribution to Ornithology of South Cameroon: 2. Passeriformes. L'Oiseau. 1973;43(3):212-259.

4. Louette M. The birds of Cameroon. An annoted check-list. Verhandeling Wetenschappen, Jaargang. 1980;43:1-163.

5. Stuart SN. Conservation of Cameroon montane forests. ICBP. 1986;250 263

6. Bowden GR. The birds of Mount Kupe, southwest Cameroon. Malimbus. 2001;23:13-44.

7. Bobo KS, Waltert M, Fichtler M, et al. New bird records for the Korup Project Area, southwest Cameroon. Malimbus. 2005;27:13-18.

8. Nguembock B. Étude phylogénétique et biogéographique de l'avifaune forestière des montagnes de l'Ouest du Cameroun. 2008.

9. Avibase. The World Birds Database. 2016.

10. Nguembock B, Mahamat S, Kemtchouan W, et al. Bird survey of AboboEtetak Hill (Yaounde, Cameroon) and a glance of the avifaunistic diversity of this hill (Abobo-Etetak). The Open Ornithology Journal. 2017;10:31-41

11. Amiet JL, Perret JL. Contribution to the fauna of the Yaoundé region (Cameroon). II Amphibians Anura. Annales de la Faculté des Sciences Cameroun. 1969;3:117-137.

12. Meyomesse SE. Geophysical study of basement aquifers in the northern sector of the city of Yaoundé (Olembé). 2011.

13. DeLancey MD, Mbuh RN, Mark WD. Historical Dictionary of the Republic of Cameroon. $4^{\text {th }}$ edn, Lanham, Maryland: Scarecrow Press. 2010 .

14. Sharpe RB. On further Collections of Birds from the Efulen District of Cameroon, West Africa. Ibis. 1904;46(1):88-106.

15. Sharpe RB. On further Collections of Birds from the Efulen District of Cameroon, West Africa, Part V \& VI. Ibis. 1908;46:119.

16. Bates GL. Anthreptes seimundi minor. Sanaga River, North of Yaounde, Cameroon. Bulletin of the British Ornithologists Club. 1926; 46:107.

17. Amiet JL. Fauna of Cameroon, Volume 2: The Genus Aphyosemion Myers/Faune du Cameroun, Volume 2: Le Genre Aphyosemion Myers (Pisces, Teleostei, Cyprinodontiformes). 2007.

18. Monard A. Résultats de la mission zoologique suisse au Cameroun. Mémoires de l'Institut Français d'Afrique Noire. Sciences Naturelles. 1951;1:59-122.

19. Decoux JP, Fotso RC. Composition and spatial organization of a bird community in the Yaoundé region. Biogeographic consequences of forest degradation and increasing aridity. Alauda. 1988;56:126-152.

20. Thebault E, Loreau M. The relationship between biodiversity and ecosystem functioning in food webs. Ecological Research. 2006;21(1):17-25

21. Parsons H, Major RE, French K. Species interactions and habitat associations of birds inhabiting urban areas of Sydney, Australia. Austral Ecology. 2006;31(2):217-227

22. Abrams PA. Effects of increased productivity on the abundances of trophic levels. The American Naturalist. 1993;141(3):351-371. 
23. Stephenie P Joyner. SAS/STAT guide for personal computers. $6^{\text {th }}$ edn 1985.

24. Microsoft Excel. Microsoft ${ }^{\circledR}$ Office Excel. 2016.

25. Pearson TH, Rosenberg R. Macrobenthic succession in relation to organic enrichment and pollution of marine environment. Oceanography and Marine Biology: an Annual Reviews. 1978;16:229-311.

26. Dajoz R. Précis d'écologie. 1982.

27. Gill F, Donsker D. IOC World Bird List. Version 7.3. 2017.

28. Borrow N, Demey R. A guide to the birds of western Africa. Princeton Universityb Press, Princeton and Oxford. 2001.

29. Christie DA, Elliott A, Kirwan GM. Handbook of the Birds of the World and BirdLife International Illustrated Checklist of the Birds of the World. Volume 2: Passerines. Lynx Edicions. UK. 2016.

30. Snow DW, Perrins CM. The Birds of the Western Palearctic. $1^{\text {st }}$ edn Oxford University Press. 1988.

31. Brown JH, Lomolino MV. Biogeography. $2^{\text {nd }}$ edn. Sinauer, Sunderland. 1998.

32. Jetz W, Rahbek C. Geographic range size and determinants of avian species richness. Science. 2002;297(5586):1548-1551.
33. Hawkins BA, Diniz Filho JAF. Beyong Rapoport's rule: evaluating range size patterns of New World birds in a two-dimensional framework. Global Ecology and Biogeography. 2006;15(5):461-469.

34. Fjeldsa J, Johansson US, Lokugalappatti LGS, et al. Diversification of African greenbuls in space and time : linking ecological and historical processes. Journal of Ornithology. 2007;148(Suppl 2):359-367.

35. Achoundong G. Ecological and floristic study of the vegetation of the Yaoundé hills above 1000m. The University of Yaounde, Cameroon. 1985.

36. Rajpar MN, Zakaria M. Bird species abundance and their correlationship with microclimate and habitat variables at natural wetland reserve, peninsular Malaysia. International Journal of Zoology. 2011;1-17.

37. Girma Z, Mamo Y, Mengesha G, et al. Seasonal abundance and habitat use of bird species in and around Wondo Genet Forest, south-central Ethiopia. Ecol Evol. 2017;7(10):3397-3405.

38. Kiros S, Afework B, Legese K. A preliminary study on bird diversity and abundance from Wabe fragmented forests around Gubre subcity and Wolkite town, Southwestern Ethiopia. Int J Avian \& Wildlife Biol. 2018;3(5):333-340. 